\title{
Beyond A "Failed" State: The Role Of Local Politics And The Informal Economy In Post-1991 Somalia.
}

\author{
Jau-Yon Chen, Ph.D. \\ Independent Academic
}

\begin{abstract}
Contrary to the stereotypical notion that a "failed" state also results in complete economic collapse, Somalia is a classic example of a vibrant economy without any functioning government institutions. For the Somali people, the informal economy has emerged not only as a daily survival mechanism; it also represents their resiliency and determination to make the best out of the worst situations. In addition to serving as Somalia's socioeconomic lifeblood, informal economic activities like livestock trade and petty commerce have kept this country linked with the global economy despite its international political isolation. This paper highlights two important themes. The first is how the informal economy in Somalia and in many war-torn nations has served as an effective grassroots response to non-existent governing systems. The second is how the localization of politics based on religious principles and traditional legal structures have played a vital role in maintaining communal peace and social order.
\end{abstract}

Keywords: Somalia, Informal Economy, and "Failed" State

\section{INTRODUCTION}

Since the disintegration of Somalia's central government in 1991, both scholars and the mainstream global media have only focused on its negative aspects and failures: violent clan warfare, public insecurity, refugee flows, and the withdrawal of international aid organizations. However, positive aspects such as: grassroots initiatives to deal with the non-existence of a central government, a vibrant informal economic sector, and the Somali people's resilience in the midst of a tumultuous environment are often overlooked. The title of Peter Little's book: Somalia: Economy Without State reflects the environments of countries like Afghanistan, Colombia, and the Democratic Republic of Congo that have been or are currently engulfed in long periods of civil war. In concordance with this book's thesis, I argue that despite Somalia's isolation from international organizations, it is still very much interconnected with the global community through its dynamic informal economic sector and the worldwide war on "terror."

In particular, the vibrancy of Somalia's informal economy brings into focus: the paradox of the modern nation-state system, alternative methods of public administration and economic management rooted in traditional legal and social structures, and grassroots strategies addressing the challenges of absent governing institutions. The objectives of this paper are three-fold: first, to examine the definition of the nation-state in a Somali context; second, to look at the alternative models of governance based on traditional customs and religious institutions; and third, to highlight the dynamics of Somalia's informal economy as a survival mechanism to state disintegration.

The paper is divided into four sections. The first looks at the localization of politics and how clan elders as well as Islamic sharia laws help enforce the rule of law and public security. The second examines the various sectors of the informal economy and their role as Somalia's socioeconomic lifeblood since 1991. The concluding section discusses both the achievements 
of the Somali civil society and the daunting challenges that this country still faces. Lastly, this paper ends with recommendations to transform Somalia from a chaotic post-war torn nation to a potential economic and tourist hub in the Horn of Africa.

\section{POLITICAL LOCALIZATION AS RESPONSE TO STATE DISINTEGRATION}

The Somali state collapsed in 1991 when its former dictator, Siad Barre was ousted in a violent civil war that had begun in the late eighties (Mubarak,1997, p.2027). What is the definition of "state collapse"? What are the characteristics of a "collapsed state," and what are its economic, political, and social consequences? According to Ken Menkhaus (2003) state collapse or failure is generally defined as: "a situation in which a central government has either lost presence in a significant portion of real estate (territorial collapse) or has lost the capacity to rule the territory in which it has a physical presence (collapse of governing capacity), or both (p. 407).

In addition, Chris Allen (1999) describes in-depth the economic, political, and social characteristics and consequences of a collapsed state. Economically, formal sector activities like agriculture, trade, manufacturing, and public sector employment gradually decreases in the absence of government oversight. Meanwhile, the informal economy expands as people struggle to make ends meet. At the same time, criminal activities such as money laundering, arms smuggling, robbery and drug trafficking proliferate as legal mechanisms to stop these activities are absent.

Politically, the central authority contracts, fragments or even disappears. State institutions and functions like law enforcement, national security provision and financial regulation declines or even disappears. Socially, the dissolution of public institutions and social services results in the erosion of societal order and moral values since no legal mechanisms exist to punish unlawful behavior and misconducts. As employment opportunities dwindle and social services are unavailable; people, especially the most impoverished ones, may resort to stealing and other petty crimes in order to survive (Allen, 1999, p. 379-380).

Although the economic, political, and social characteristics of a collapsed state described above apply to Somalia after 1991, this country's central government had already showed signs of disintegration before its official collapse. Peter Little (2003) points out, "the state is 'a relatively empty shell'" for the majority of Somalis because even when the central government was present, it did not carry out vital functions of providing social services like public health, education, electricity or running water (p. 123 and 169). Besides the lack of public services, the biggest problem for Somalia and for most Sub-Saharan African countries is the mismatch between the state and society. One Somali intellectual, Abdalle Omar Mansur interviewed in Virginia Luling's (1997) "Come Back Somalia? Questioning a Collapsed State" states: "the most serious problem in Somalia today is that our cultural traditions are not compatible with the construct of a modern state" (p. 289).

The modern "nation-state" in Somalia and in the rest of Sub-Saharan Africa is a colonial creation, which conflicts with the indigenous socioeconomic structure. Lamentably, the colonial apparatus of the "nation-state" was continued after Somalia's and Sub-Saharan Africa's independence. In Somalia, the social structure within the nation-state framework is not only largely pastoral and nomadic; it is also based on clan membership. The Somali clan is "a system of groups linked genealogically by descent through the male line” (Ibid, 1997, p. 289).

Interestingly, clanship is one of the main causes of division and unity of the Somali nationstate. Unfortunately, instead of resolving conflicts among different clans, the nation-state structure further exacerbated this problem. Under this structure, all the essential resources 
like land, water, and cattle grazing are concentrated in the hands of the central government, which intensifies the economic and political competition among various clans (Ibid, 1997, p.290). Moreover, the central government is an instrument for the ruling clan to enrich themselves at the expense of the general population by appropriating important economic resources and by using the legal and military institutions plus other available public resources to protect their special privileges. Sadly, the Somalis only had negative experiences with the modern nation-state since its formal creation in 1960. Instead of promoting law and order, the nation-state promoted lawlessness and disorder because it became a tool for the ruling elite to exploit and oppress the people (Menkhaus, 2003, p. 408-409).

The dissolution of the Somali state has negative impacts like: hiatus in provision of basic services (electricity, water, and sanitation); exodus of civil administrators, skilled professionals, and medical personnel; educational deprivation of a large young population; increase in illicit economic practices; and widespread discrimination and attacks on vulnerable clans and minorities (Little, 2003, p. 124 and Mubarak, 1997, p. 2030). Ironically, the disintegration of the central government also has positive effects. Despite the lack of a national governing authority, some places in Somalia had enjoyed relatively high levels of peace, security, and social order. Unfortunately, in many developing nations, particularly in SubSaharan Africa; having a central government does not necessarily guarantee the presence of law, public security, and social order. Menkhaus (2003) points out that paradoxically, lawlessness and armed conflicts were worse on the Kenyan border with Somalia even though the former has a functioning central government. Jamil Mubarak (1997) further states that "the vanishing of state institutions was a blessing for the domestic market in many ways" (p. 2030) because repressive economic policies of excessive state regulation and market intervention along with the corrupt functionaries of Siad Barre's government had disappeared with the dissolution of the state. For the most part, Somalia's domestic market was free of government regulations and bureaucratic controls until mid-1995.

Localization of politics became a widespread phenomenon with the disintegration of the central authority. To ensure law, public security, and societal order, the Somali public has resorted to Islamic values and institutions as well as traditional customs. Menkhaus (2003) describes (p. 123) best portrays post-1991 Somalia. "Even though Somalia is stateless, it is not anarchic. Repeated efforts to revive a central government have failed. However, local communities have responded with a wide range of strategies to establish law and order. What has emerged (in this country) after 1991 are fluid, localized polities involving authorities as diverse as clan elders, professionals, militia leaders, businessmen, traditional Muslim clerics, Islamic fundamentalists, and women's associations." Lamentably, the alternative ways of governance in post-1991 Somalia are often overlooked by scholars and the international media. In the midst of state collapse and widespread civil strife, local politics and informal systems of governance rooted in traditional sociopolitical structures have ensured public security and societal order (Menkhaus, 2003, p. 411).

The important actors in Somalia's local politics and governance are: the traditional council of clan elders, the Islamic clergy and court system, and in some cases, livestock traders or businessmen. The council of clan elders is the principal institution in most Somali communities. The clan elders' power and legitimacy come from their special status in their clans. They act as a supreme body and are expected to provide wisdom and help build consensus among clan members, especially during crises. Their authority and power are also supported by the Islamic sharia laws as well as by Somalia's traditional legal framework of diya principles and xeer customary laws. The diya principles are rules that determine compensation for death and injury between different groups plus sanctions against violence and misconduct. 
Meanwhile, the xeer laws cover areas of marriage, war, land and natural resource use. Additionally, the clan militia and local police also assist the elders to enforce the xeer and diya laws and penal codes. In some cases, the clan elders have even built alliances among different clans and sub-clans to develop common security agreements and form local civil administrations (Little, 2003, p.154-55; Menkhaus, 2003, p. 411-12; Mubarak, 1997, p. 2034$35)$.

Besides the council of clan elders, Islam also plays a pertinent role in all aspects of Somali society since the population is predominately Muslim. The need for public security has expanded the Muslim clergy's power base and the application of strict sharia laws, especially when clan elders and local militias have failed to provide order and security. The sharia courts represent local efforts to provide essential government functions in the ambiance of state dissolution. Not only are these court systems widely embraced and supported by local communities as ways of restoring law and order; they are also usually administered by Muslim clergies, clan elders, and businessmen who are strongly opposed to fundamental Islam. In addition to law enforcement, Muslim organizations have also filled some educational voids left by the state by helping to re-open schools through financial support from Arab countries (Ibid, 2003, p. 154; Ibid, 2003, p. 409; Ibid, 1997, p. 2034-2035).

Furthermore, other civil society actors such as livestock traders and women's organizations are also active participants in local politics and administration. With their vast networks of contacts and experience in negotiating business agreements, some livestock traders have assumed leadership positions and played pertinent roles in peace negotiations. As peace is essential to their trade, business pressures for safe and open roads have been crucial in peace negotiations. For example, an association of khat traders formed the Somali Business Association's Party in 1998 to help lobby for peace agreements so that their goods could move freely without extortion or harassment. Moreover, businessmen and traders have also helped to cover security service costs for the public in larger towns. In addition to businessmen, women's grassroots groups serve as vocal supporters of peace and strong critics of clan warfare. They have contributed to Somalia's peace process by organizing vocal and visible demonstrations to foment political action for peace and by participating in peace negotiations in Djibouti and in Mogadishu's business sectors (Little, 2003, p. 152-153).

Although local politics and grassroots action have provided effective governance in their communities, there are limitations. For instance, the sharia courts could not extend their authorities beyond their local communities, the rule of law only applies within but not outside of clans adhering to the sharia legal system, and the enforcement of law is not always consistent. Additionally, the clan elders may not have the authority or the power to disarm militias and armed youth gangs (Luling, 1997, p. 298; Menkhaus, 2003, p. 409).

\section{INFORMAL ECONOMY AS EXPRESSION OF PEOPLE'S RESILIENCE}

Even though there is no precise definition of the informal economy, in the Somali context, this sector could be defined as: "economic actions that bypass the costs and are excluded from the protection of laws and administrative rules covering 'property relationships, commercial licensing, labor contracts, torts, financial credit, and social security systems'” (Portes, 1994, p. 428). In the industrialized world, the collapse of government institutions would devastate the national economy. However, in Somalia and countries in turmoil like Afghanistan, Iraq, Colombia, and the Democratic Republic of Congo, certain key economic sectors still thrive in the midst of government failure. For example, Somalia's livestock trade and informal banking system were performing better after the central government fell apart. The system of the informal sector works in Somalia and in many other parts of the world because economic 
relationships and interactions are not solely contingent upon financial exchange or the legal institutions' judicial enforcement of commercial agreements and contracts. Instead, the relationship is rooted in family, friendship, clanship, ethnic or other forms of social ties and obligations that could be invoked if an agreement is violated. This serves as an alternative to the enforcement mechanisms of legal institutions in the industrialized world and in some highincome developing nations (Little, 2003, p. 83 and 108).

Somalia's informal economic sector was well-established even before the state collapsed in 1991. This sector emerged in response to the economic crises caused by the government's poor economic management and macroeconomic policies. Tragically, this country's official economy was already in an abysmal condition during the final years of Siad Barre's regime. Although the Barre government had implemented free market policies in the eighties; lamentably, the overall national environment was not conducive to private sector economic activities due mismanagement and the gradual decline of key governing institutions. Corruption, absenteeism, and lack of motivation were prevalent among government employees as their wages had drastically decreased. State policies were repressive and had little credibility. The excluded urban private sector was forced to join the informal market in order to survive and make ends meet. Illicit activities such as smuggling of drugs as well as the black marketeering of foreign exchange became widespread. From 1989 to 1990, the non-financial public sector deficit had exceeded thirty percent of the country's Gross Domestic Product and the total outstanding foreign debt over the GDP was approximately $240 \%$ in 1988 and $277 \%$ in 1990 (Mubarak, 1997, p. 2028-29).

Paradoxically, the end of the central government had resulted in positive economic effects because when the government was in existence, the Somali shilling was unstable and experienced large fluctuations in its exchange values with the American dollar due to corruption and poor monetary policies. Throughout the eighties, the Somali shilling had lost its real market value by as much as three hundred percent in some years. After the state had disintegrated in 1991, there was little or no political tampering with neither the monetary system nor theft of national accounts. These were the two principal actions that had destabilized the Somali economy in the eighties. Additionally, there were no fears of financial repression and inflationary financing of public sector deficits. People traded freely and openly in goods and services and in foreign currencies (Little, 2003, p. 141 and Mubarak, 1997, p. 2030).

One of the most amazing aspects about the post-1991 Somali economy is the stability and continued circulation of the old Somali shilling because it did not have the backing of a central bank since 1991. This currency has maintained its value and was exchangeable with other currencies: the Kenyan shilling, Ethiopian birr, Djibouti franc, Saudi riyal, and American dollar. Since there is neither a central governing institution nor agreement among the general public, there has been no printing of a new currency that would be acceptable to everyone. The majority of people, especially traders and businessmen, have decided to keep using the old currency to facilitate financial transactions in the absence of another widely available currency. Additionally, the US dollars had emerged as a backup currency for the Somali shilling as a result of its huge circulation into the local economy during the United Nations' presence in the country. When the UN and other foreign aid organizations left Somalia in the middle of 1995, the American dollar continued to circulate in the Somali market through remittances, export revenues, local consumption, and cross-border trading with neighboring countries. Most of all, the Somali shilling was stronger than its neighboring currencies after 1995. From July 1995 to February 1999, there was about a $26 \%$ decline in the Somali shilling, from 6,500 to 8,200 shillings per USD. On the other hand, the Kenyan shilling dropped 36\%, from 45 to 61 shillings 
per USD while the Ethiopian birr experienced a 27\% decline. From January 1996 to March 1999 , the changes in the value of the Somali shilling rarely exceeded five to ten percent per month. Since its exchange rate was reasonably stable compared to the neighboring currencies, the Somali shilling had facilitated cross border trade and international commerce (Little, 2003, p. 139 and 145; Mubarak, 1997, p. 2031).

Besides stability in the Somali currency, foreign investment and trade with well-known international firms like General Motors of Kenya also took place in spite of the absence of an internationally recognized government. The lack of a central government and national institutions such as a central treasury did not discourage legitimate transnational corporations from establishing branch companies or subsidiaries in Somalia. For example, Dole Fruit Incorporated and Italian agribusiness companies had invested in Somalia's agricultural sector in the nineties. For now, this country also has services from global couriers like DHL and Federal Express. The activities of international firms further complicate the combination of formal and informal economic features in Somalia because their presence formalizes certain aspects of the informal economy. Even though this country's economy and current Transnational National Government are not officially recognized by intergovernmental organizations, it has not discouraged international business operations. By doing business in Somalia, multinational companies add an element of economic and political legitimacy to this country (Little, 2003, p. 4 and 166-67).

Moreover, large remittance flows from the Somali diaspora working and living abroad have contributed to the development and expansion of Somalia's dynamic informal economy. According to an USAID report written in the late nineties (Ahmed 2000), the total annual amount of remittances to Somalia in 1998 is about four million dollars, and approximately 120,000 households are recipients of remittances from abroad. Overseas remittances are significant not only because they have created the growth of telecommunications and money transfer companies to facilitate financial transfers; they have also dispelled the stereotypical notion that war-torn nations like Somalia are entirely dependent upon foreign aid for survival when in fact, ordinary citizens are proactively keeping their countries' economies afloat. The importance of remittance flows has significantly increased since the outbreak of civil war in 1988. From the early nineties, remittances have replaced livestock exports as the main source of foreign exchange earnings. During the mid to late 2000s, the size of Somalia's annual remittances is approximately four times the value of its livestock exports. Furthermore, remittances have also financed the country's entire import bill, especially when Saudi Arabia banned livestock imports from Somalia in 1998 (Ahmed, 2000, p. 380-88).

Another pertinent impact generated by remittances is the improvement of Somalia's telecommunications infrastructure and technology. This is one of the country's major accomplishments since the national government had dissolved. By the mid-2000s, five telecommunications companies have established rapid expanding telephone networks throughout this country. These five companies have provided one of the cheapest telephone services in East Africa by using a microwave system that does not require expensive land cables. These telecommunications networks have reached even the most remote rural areas. Although the telecommunications system was originally established to facilitate remittance transfers and communications between Somali migrants and their families, the availability of inexpensive telephone services has also aided numerous business transactions between Somalia and the Gulf States (Ibid, 2000, p. 380-88).

On the whole, Somalia's informal economy is its socioeconomic lifeblood since 1991. This sector has filled certain economic and social voids caused by the breakdown of government 
institutions. By the mid-eighties, most employment opportunities were concentrated in the informal sector. The informal economy has helped provide health, educational, and financial services plus credit and investment financing to small producers as access to the official credit market was possible only to those with political connections. Furthermore, the informal banking system also gives traders access to foreign exchange in addition to facilitating remittance transfers.

On an international scale, informal flows of finance and trade have connected Somalia and most of Sub-Saharan Africa to the global economy. The advantage that post-1991 Somalia offers for cross-border trade to Kenya and other neighboring countries is tax-free imports. Consumer products like electronics and second-hand clothing are imported 'duty-free' from the United Arab Emirates through Somali ports and end-up in Kenyan markets via Somali border towns. Kenya's cheapest consumer electronics and products are sold in communities close to the Somali border as large-scale Somali traders have partners and business networks in the UAE to facilitate trade in consumer goods.

Since the mid-2000s, Somalia has become as a strategic location for the flow and exchange of commodities from Asia and the Middle East to be traded tax-free throughout the African continent. Above all, one of the informal economy's most positive externalities is the promotion of peace. As business opportunities and interests have changed from a war economy based on looting and arms trading to one based on extensive trans-regional commerce and remittance flows, business groups in various economic sectors have greater interests in establishing a safe and stable social environment free of robbery and extortion at militia checkpoints (Little, 2003, p. 118 and 166-67; Menkhaus, 2003, p. 417; Mubarak, 1997, p. 2029 and 2038).

In spite of the positive impacts, Somalia's informal economic sector also has its limitations. Post-1991 Somalia represented 'one of the purest laboratories' for capitalism as some businesses have survived and even prospered in the absence of a national government. However, this environment did not benefit everyone equally nor solve the structural problems underlying clan warfare and contraction of the formal economic sector. In general, this country's economic growth is chaotic and suffers from the lack of an organized, efficient, longterm public administration that could provide social services plus a stable economic, political, and social environment that is conducive for steady economic growth and development. The employment opportunities generated by the informal economic sector are ephemeral and unsustainable. There are still large displacements of people and outflows of Somali refugees due to ongoing civil strife.

Unfortunately, the informal economy could only generate pressures for peace but not guarantee it. The need for a stable sociopolitical climate in order to conduct business does not automatically create nor re-establish vital public institutions. This sector could not fulfill every important government function like providing free primary education or potable water for impoverished rural communities. Moreover, the absence of formal banking institutions and financial organizations has discouraged deposits and savings as well as made credit generation difficult. This in turn limits the remittances' potentials to stimulate long-term economic development in the country.

Since there are no formal financial institutions like Barclays or Citibank to facilitate credit schemes or savings, most Somali migrants and businessmen keep large portions of their capital and finances abroad. Sadly, the massive capital, financial and human resource flight during the civil war could not be fully reversed. As a result, private investment and entrepreneurial 
activities in Somalia remain small-scale, short-term, and opportunistic (Ahmed, 2000, p. 388; Little, 2003, p.123; Mubarak, 1997, p. 2033-34 and 2038).

\section{CONCLUSION}

The case of Somalia demonstrates that a collapsed state does not mean complete anarchy or chaos as people have found ways to ensure a functioning society. When formal economic sectors have waned, people kept the country's economy afloat through social networks and links to the global economy. As one young Somali man states in Luling's article (1997) that after 1991, "Somalis have come to rely on themselves, and this is working. No one is helping them, there is no government and business is booming. Everyone is working for him or (for) herself, there is no welfare system" (p. 300). This statement reflects the phenomenal abilities of ordinary Somalis to adapt and thrive in a tumultuous environment. For instance, in Somaliland (Somalia's northwest autonomous region since 1991), a group of former Somali National Movement (SNM) guerilla fighters had established Havoyoco, one of this region's oldest nongovernmental organizations, to operate a waste collection company for the local municipal government. Moreover, due to the prolonged absence of a functioning central government, many Somali women were forced to work outside of the home to support their families. In the process, not only have they learned new-income earning skills, but also elevated their status as they became the main income provider for their families (Mackie et al., 2017, p. 369 and 373).

Despite the success of grassroots efforts to make the best out of the worst circumstances, this country still faces two daunting challenges. First, even though a central government, backed by international organizations, has been re-established in Somalia since 2012; the country is still plagued by poor institutional capacities. This in turn has hampered the government's abilities to collect taxes from the informal economic sector. (Mwiti, 2015). Taxes are the source of a government's ability to provide basic public goods such as education, health care, and transportation networks. The lack of a steady tax base has slowed the process of Somalia's full post-conflict recovery and hindered the development of a functional formal economy (Shiino, 2016). Second, due to the country's two decade long civil war, there still remains a large young population that has received little or no formal education. This, along with unsteady job opportunities in the informal economic sector, has resulted in a high youth unemployment rate, with seven out of ten young people being unemployed as of 2014. To make ends meet, many young men became pirates, which in turn has created national security issues and negatively impacted Somalia's international reputation (Young, 2014).

\section{RECOMMENDATIONS}

To address the two challenges mentioned in the previous section, the Somali government must implement measures to combat corruption, piracy, and rampant circulation of counterfeit Somali shilling notes (the country's currency). An important first step is to institute monetary reforms that include: strengthening the credibility of money transfer businesses and improving the government's overall statistical capabilities and budget management (Mwiti, 2015). Additionally, it must increase its investments in education with the objectives of reducing high female illiteracy rate, enhancing the technical and managerial skills of Somali youth, and providing further access to micro-finance for small and medium business owners (Mackie et al., 2017, p. 376 and 379). As mobile technology has become ubiquitous in the country since the mid-2000s, it possesses enormous potentials to become Somalia's very first prosperous formal economic sector. Therefore, the Somali government must encourage additional investments by both foreign companies and overseas Somalis in this area because its success will generate stable employment opportunities along with a viable tax base (Shiino, 2016). 
In addition to mobile technology, another potential formal economic sector is tourism. Despite the security risks, Somalia's beautiful, breath-taking, and pristine beaches along the Indian Ocean have attracted a small number of international tourists in the last eight years. According to the current Lonely Planet website: "If Somalia does open-up for travel, visitors will again be able to experience its fascinating culture and enjoy its natural attractions, bask on pristine beaches and trek across arid mountains." This statement is reflected in the development of numerous luxury accommodations and upscale dining establishments along the popular tourist destinations of Lido, Gezira, and Jazeera Beaches (Lonely Planet Forum, 2016). With good infrastructure, management, full government support, and diaspora involvement; tourism and mobile technology can become the two main formal economic sectors to propel Somalia's national development and greatly improve its international image.

\section{References}

Ahmed, I. I. (2000). Remittances and Their Economic Impact in Post-War Somaliland. Disasters, 24(4), $380-389$.

Allen, C. (1999). Warfare, Endemic Violence and State Collapse in Africa. Review of African Political Economy, 26(81), 367-384.

Little, P. (2003). Somalia: Economy Without State. Bloomington: Indiana University Press.

Lonely Planet Forum-Africa-Thorn Tree. (2016). All Tips About Mogadishu, Somalia 2016 Fun and Tourism. Message Posted to https://www.lonelyplanet.com/thorntree/forums/africa/topics/all-tips-about-mogadishusomalia-2016-fun-and-tourism

Lonely Planet. (n.d.) Welcome to Somalia. Retrieved March 2, 2019, From https://www.lonelyplanet.com/somalia Luling, V. (1997). Come Back Somalia? Questioning a Collapsed State. Third World Quarterly, 18(2), $287-302$.

Mackie, P., Brown, A., Dickenson, K., Ahmed, E., Hassan, S., \& Barawani, M. (2017). Informal Economies, Conflict Recovery and Absent Aid. International Institute for Environment and Development, 29(2), 365-382. doi: 10.1177/0956247817719868

Menkhaus, K. (2003). State Collapse in Somalia: Second Thoughts. Review of African Political Economy, 30(97), 405-422.

Mubarak, J. (1997). The 'Hidden Hand' Behind the Resilience of the Stateless Economy of Somalia. World Development, 25(12), 2027-2041.

Mwiti, L. (2015, August 3). What Are Somalia's Biggest Economic Challenges? World Economic Forum. Retrieved From https://www.weforum.org/agenda/2015/08/what-are-somalias-biggest-economic-challenges/

Portes, A. (1994). The Informal Economy and Its Paradoxes. Handbook of Economic Sociology. Ed. Neil J. Smelser and Richard Swedberg. New York: Russell Sage, 426-447.

Shiino, A. (2016, January 13). The Economic Future of Somalia. Horseed OP-ED. Retrieved From https://horseedmedia.net/2016/01/13/the-economic-future-of-somalia/

Young, H. (2014, August 20). Driven by Unemployment, Youth in Somalia Turned to Piracy as a Solution. The Guardian. Retrieved From https://www.theguardian.com/global-development-professionalsnetwork/2014/aug/20/youth-unemployment-interactive-mohamed-ali 